\title{
Establishment and characterization of a paclitaxel-resistant human esophageal carcinoma cell line
}

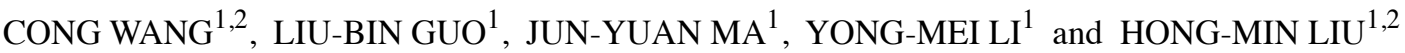 \\ ${ }^{1}$ School of Pharmaceutical Science, Zhengzhou University; ${ }^{2}$ New Drug Research and \\ Development Center, Zhengzhou University, Zhengzhou 450001, P.R. China
}

Received June 24, 2013; Accepted August 5, 2013

DOI: $10.3892 /$ ijo.2013.2083

\begin{abstract}
The aim of this study was to establish a new paclitaxel (PTX)-resistant human esophageal squamous carcinoma (ESCC) cell line and investigate its biological characteristics. The resistant cell line (EC109/Taxol) was developed in vitro by intermittent exposure of the human ESCC cell line EC109 to a high concentration of PTX with time-stepwise increment over a period of 6 months. The MTT assay was performed to test the drug resistance of EC109 and EC109/Taxol cells. The morphological features were observed using inverted microscopy and apoptosis was measured by flow cytometry (FCM) and Hoechst 33258 fluorescence staining. Cell growth curves and colony formation of EC109 and EC109/Taxol cells were compared. FCM was also used to determine the distribution of the cell cycle. The protein levels of $\mathrm{Bcl}-2$, Bax, Procaspase-3 and P-gp were detected by western blotting. P-gp activity was evaluated by Rh123 accumulation and efflux assay. In vivo resistance characterization was investigated. EC109/Taxol cells were 67.2-fold resistant to PTX in comparison with EC109 cells, and also exhibited cross-resistance to 5-fluorouracil (5-FU), cisplatin (CDDP) and epirubicin (EPI). FCM and Hoechst 33258 fluorescence staining confirmed that EC109 cells treated with PTX showed significantly higher percentage of apoptotic cells compared to EC109/Taxol cells. Simultaneously, EC109/Taxol cells exhibited changes in morphology, proliferation rate, doubling time, cell cycle distribution and colony formation rate were detected as compared with EC109 cells. The resistant cell line overexpressed Bcl-2, Procaspase- 3 and P-gp protein, and showed decreased Bax expression. Further, EC109/Taxol cells did not change PTX resistance in vivo. This is the first report on the establishment of an EC109/Taxol cell line with higher resistance. Bcl-2, Bax, Procaspase-3 and P-gp are involved in
\end{abstract}

Correspondence to: Professor Hong-Min Liu or Dr Cong Wang, School of Pharmaceutical Science, Zhengzhou University, Ke Xue Da Dao 100, Zhengzhou 450001, P.R. China

E-mail: liuhm@zzu.edu.cn

E-mail: wangcong@zzu.edu.cn

Key words: human esophageal carcinoma cell, paclitaxel, multidrug resistance the resistance of cell lines to PTX, which are invaluable tools to study the resistance of anticancer drugs and to identify the methods to overcome resistance.

\section{Introduction}

Esophageal carcinoma (EC) is the sixth leading cause of cancer-related mortality and the eighth most common form of cancer worldwidely. It affects more than 450,000 people around the world and the incidence is increasing rapidly (1-5). The overall 5-year survival rate ranges from $15 \%$ to $25 \%$, and the best outcomes are associated with disease diagnosis in the early stages (6). Most esophageal cancers in China belong to squamous cell carcinomas (SCCs), which are different from adenocarcinomas, the most prevalent esophageal cancers in Western countries. This leads to distinct difference in etiology, therapeutics and prognosis (7). To treat this cancer, chemotherapy is considered as one major choice of treatments. However, the success of chemotherapy depends on the sensitivity of the tumor to the antineoplastic agents. Esophageal carcinoma cells often acquire resistance to drugs and even develop multidrug resistance (MDR). MDR inhibits effective therapy and is the most common cause of the chemotherapybased treatment failure. Numerous clinical data reveal that the multidrug resistance in tumor is related to the death of more than $90 \%$ of tumor patients. Multidrug resistance is defined as cancer cells exposed to one drug may produce cross-resistance to other drugs, which possess obviously different structures and functions (8). The intrinsic and acquired resistance to multiple chemotherapeutic drugs are major obstacles in the clinical treatment of cancer, and the mechanisms responsible for MDR remain unclear (9). Paclitaxel (PTX) is an active anticancer agent used to treat a broad spectrum of tumors, including esophageal carcinoma (10). As a promoter of tubulin polymerization, PTX changes the dynamic equilibrium of assembling and disassembling microtubules, disrupts the formation of the normal spindle at metaphase, and causes a blockade of mitosis at $\mathrm{G}_{2} / \mathrm{M}$ phase $(11,12)$. PTX is frequently used in all clinical protocols of chemotherapy and is also an important drug to treat esophageal carcinoma, but resistance has been observed in clinical practice. Therefore, a solution to reduce the resistance of esophageal carcinoma to PTX is necessary for the treatment and prognosis of esophageal carcinoma. In this study, to elucidate the mechanism of MDR in EC109, a 
PTX-resistant human EC109 cell line with MDR phenotype was established as closely as possible to the conditions actually occurring in clinical treatment. The cell line can be set as a model for investigating chemotherapy resistance. The biological characteristics and possible mechanisms involved in MDR were investigated.

\section{Materials and methods}

Drugs and reagents. PTX, 5-fluorouracil (5-FU), cisplatin (CDDP), and epirubicin (EPI) were purchased from Hainan General Kangli Pharmaceutical Co., Ltd. (Haikou, Hainan, China), Shanghai Xudong Haipu Pharmaceutical Co., Ltd. (Shanghai, China), Qilu Pharmaceutical Co., Ltd. (Jinan, Shandong, China), Zhejiang Hisun Pharmaceutical Co., Ltd. (Taizhou, Zhejiang, China) and stored at a concentration of $6 \mathrm{mg} / \mathrm{ml}, 25 \mathrm{mg} / \mathrm{ml}, 1 \mathrm{mg} / \mathrm{ml}$ and $1 \mathrm{mg} / \mathrm{ml}$ at room temperature, respectively. Dimethylsulfoxide (DMSO) was obtained from Tianjin Deen Chemical Reagent Co., Ltd. (Tianjin, China). 3[4,5-dimethylthiazol-2-yl]-2,5-diphenyl-tetrazolium bromide (MTT), rhodamine 123 (Rh123) and propidium iodide (PI) were from Sigma (St. Louis, MO, USA). RNase A was from Solarbio (Beijing, China). Mouse monocolonal antibody against P-gp is the product of Santa Cruz Biotechnology Inc. (Santa Cruz, CA, USA). Rabbit monocolonal antibodies against Bcl-2, Bax and Procaspase-3 came from Zhongshan Goldenbridge Biotechnology Co., Ltd. (Beijing, China).

Cell line and cell culture. The EC109 cell line was obtained from the Chinese Academy of Sciences (Shanghai, China). The cells were cultured in RPMI-1640 medium (Hyclone, Beijing, China) supplemented with $10 \%$ fetal bovine serum (FBS, Hyclone), $100 \mathrm{U} / \mathrm{ml}$ of penicillin (North China Pharmaceutical Group Co., Shijiazhuang, Hebei, China), and $100 \mu \mathrm{g} / \mathrm{ml}$ of streptomycin (North China Pharmaceutical Group Co.) at $37^{\circ} \mathrm{C}$ in a humidified air atmosphere containing $5 \% \mathrm{CO}_{2}$ and were used for the in vitro experiments.

Animals. Female 6-week-old BALB/c nu/nu mice weighing 18-19 g each were purchased from Hunan Lake King of laboratory animal Co., Ltd. (Changsha, Hunan, China), and maintained under specific pathogen-free (SPF) conditions at $25^{\circ} \mathrm{C}$ in an atmosphere with $50 \%$ humidity for the studies. Lighting was operated automatically on a $12 \mathrm{~h} \mathrm{light/dark}$ cycle. All experimental animals were housed under SPF conditions for 1 week to get accustomed to the surroundings before the initiation of experiment. The animals had free access to sterilized food and water. All procedures were performed in accordance with Institutional Animal Care and Use Committee guidelines.

Establishment of the PTX-resistant cell line, EC109/Taxol. The resistant cell line was established in vitro by intermittent exposure of human EC109 to a high concentration of PTX with time-stepwise increment. PTX was added to the cells at pulse treatment of $0.625 \mu \mathrm{g} / \mathrm{ml}$ for $2 \mathrm{~h}$ when they grew to $70-80 \%$ confluence. The treated cells were then washed three times with phosphate buffered saline (PBS) and cultured in PTX-free growth medium. The majority of the cells were dead within $24 \mathrm{~h}$ of exposure to PTX. The dead cells were washed out with PBS and fresh medium again added daily. After an incubation of $4-5$ weeks at $37^{\circ} \mathrm{C}$ in a humidified air atmosphere containing $5 \% \mathrm{CO}_{2}$, the surviving cells restored to exponential growth without pressure of PTX, and were then cultured without PTX for 3 passages. The above treatment was repeated three times. Thereafter, PTX was added to the cells at pulse treatment of $0.625 \mu \mathrm{g} / \mathrm{ml}$ for $4 \mathrm{~h}$ after they had proliferated to normal status, and this cyclic treatment was repeated three times. The PTX-resistant cell line EC109/Taxol was established six months after the treatment was initiated, then the resistant phenotype was developed. The resistant cells were then cultured without PTX for three passages and frozen in the liquid nitrogen. Freeze-stored cells were recovered after three passages and were subjected to the identification of biological characteristics, and the following experiments.

Drug sensitivity assay. The MTT method was applied to investigate the sensitivity of the cell strains EC109 and EC109/Taxol to the drugs PTX, 5-FU, CDDP and EPI. Briefly, EC109 and EC109/ Taxol cells were harvested during the exponential growth phase following trypsinization (Beyotime Institute of Biotechnology, Shanghai, China). Cells $\left(8 \times 10^{4}\right.$ cells $\left./ \mathrm{ml}\right)$ were inoculated into each well in 96-well plates (Nest Biotechnology Co., Ltd., Wuxi, Jiangsu, China) with $100 \mu \mathrm{l}$ culture medium. After an overnight incubation, the medium was removed and replaced by various concentrations of the drugs mentioned above. Seven or eight different concentrations for each drug were applied. Medium without drug was added to the control and blank wells. The plates were incubated at $37^{\circ} \mathrm{C}$ in $5 \% \mathrm{CO}_{2}$ for $48 \mathrm{~h}$. Thereafter, the cells were cultured for $4 \mathrm{~h}$ at $37^{\circ} \mathrm{C}$ with $20 \mu \mathrm{l}$ of $5 \%$ MTT in each well. MTT solution was removed and the insoluble formazan crystals were dissolved in $150 \mu \mathrm{l}$ of DMSO. The mixture was shaken for $10 \mathrm{~min}$ at room temperature. Cell viability was determined based on the mitochondrial conversion of MTT to formazan. The amount of MTT converted to formazan is a sign of the number of viable cells. The absorbance was measured using a microplate reader (BioTek Instruments, Inc. Vermont, USA) with a test wavelength at $490 \mathrm{~nm}$. All data points represent the mean of a minimum of 6 wells. Absorbance levels from drugtested cells were corrected against untreated control absorbance values. SPSS 17.0 was used for data analysis. Cells treated with media only served as the indicator of $100 \%$ cell viability. All experiments were performed at least three times. IC50, the half maximal inhibitory concentration, represents the concentration of the modulators that is required for $50 \%$ inhibition of cells. The cell resistance index (RI), as a parameter of resistance potency, was determined by the ratio of the IC50 values of EC109/Taxol to EC109 cells.

Analysis of morphological changes. Exponentially growing EC109 cells and EC109/Taxol cells were observed under the inverted light microscopy and photographed by a Panasonic Lumix DMC-FH25.

Apoptosis assay using Hoechst 33258 staining and flow cytometry (FCM). Hoechst 33258 (bisbenzimide Hoechst NO33258) was purchased from Beyotime. Cells were seeded on glass slides placed in 6-well plates for $24 \mathrm{~h}$. After growing to approximately $40-50 \%$ confluence, the cells were treated with 0,50 and $100 \mathrm{nM}$ of PTX for $24 \mathrm{~h}$. The cells then were 
washed with PBS three times followed by fixation with $4 \%$ paraformaldehyde for $15 \mathrm{~min}$, then washed three times with PBS. Hoechst 33258 was subsequently added at a final concentration of $10 \mu \mathrm{g} / \mathrm{ml}$ in dark for $30 \mathrm{~min}$. After washing with PBS, the slides seeded with the cells were mounted and analyzed by fluorescence microscopy. Apoptotic cells were identified on the basis of morphological changes in their nuclear assembly by observing chromatin condensation and fragment staining with Hoechst 33258.

An Annexin V-Fluorescein isothiocyanate kit (Annexin VFITC, Nanjing KeyGEN Biotech CO., Ltd., Nanjing, Jiangsu, China) was used to detect apoptosis. Briefly, cells were seeded in 6-well plates and treated with 0, 50 and $100 \mathrm{nM}$ of PTX for $24 \mathrm{~h}$. Then the cells were harvested by brief trypsinization, washed twice with ice-cold PBS, and resuspended in binding buffer [10 mM 4-(2-hydroxy-ethyl)-1-piperazineethanesulfonic acid (HEPES), pH 7.4, $150 \mathrm{mM} \mathrm{NaCl}, 2.5 \mathrm{mM}$ $\mathrm{CaCl}_{2}, 1 \mathrm{mM} \mathrm{MgCl} 2,4 \%$ bovine serum albumin] containing Annexin V-FITC $(0.5 \mathrm{mg} / \mathrm{ml})$ and PI $(0.5 \mathrm{mg} / \mathrm{ml})$. After $15 \mathrm{~min}$ incubation in dark at room temperature, stained cells were immediately analyzed by Accuri C6 flow cytometer (Becton, Dickinson \& Co., Franklin Lakes, NJ, USA). Apoptosis cells were determined by Annexin V-positive and PI-negative cells (13). The cell apoptosis rate was calculated as: Apoptosis rate = (apoptotic cell number/total cell number) x100\%.

Growth curves and the doubling time (Td). Single-cell suspensions were prepared from the cells in exponential growth phase. Aliquots containing 14,000 cells were seeded in 24-well plates (Nest Biotechnology Co., Ltd.) with $1 \mathrm{ml}$ of medium at $37^{\circ} \mathrm{C}$ in a humidified air atmosphere containing $5 \% \mathrm{CO}_{2}$ incubator. Three wells were used for each determination, and three cell counts for each well from each cell line were made every $24 \mathrm{~h}$ for 7 days. The doubling time (Td) of each cell line was counted according to the formula: $T d=T x \lg 2 /\left(\lg N_{t}-\lg N_{0}\right)$, where $\mathrm{N}_{0}$ is the cell number at the beginning, $\mathrm{N}_{t}$ is the cell number of cells harvested, and $\mathrm{T}$ is the time from $\mathrm{N}_{0}$ to $\mathrm{N}_{\mathrm{t}}$.

Colony formation assay. Cell were trypsinized, counted, and seeded into 6-well plates at $1 \times 10^{3}$ cells per well. Plates were incubated at $37^{\circ} \mathrm{C}$ in a humidified air atmosphere containing $5 \% \mathrm{CO}_{2}$ incubator for 7 days. Cells were then fixed with $95 \%$ ethanol for $30 \mathrm{~min}$, stained with $1 \%$ crystal violet and cell colonies ( $\geq 50$ cells) were counted under inverted light microscopy. Images of representative colonies were photographed by a Panasonic Lumix DMC-FH25. The colony formation rate was calculated as (colony counts)/(cells inoculated) $\mathrm{x} 100 \%$.

Determination of cell cycle distribution by FCM. EC109 and EC109/Taxol cells were harvested during the exponential growth phase following trypsinization. The cells were washed with cold PBS and fixed by suspending the cells in ethanol at $4^{\circ} \mathrm{C}$ overnight. The fixed cells were washed and resuspended in $200 \mu \mathrm{l}$ PBS containing $50 \mu \mathrm{g} / \mathrm{ml} \mathrm{PI}$ and $50 \mu \mathrm{g} / \mathrm{ml}$ RNase A. Then, the samples were incubated at $37^{\circ} \mathrm{C}$ for $30 \mathrm{~min}$ in the darkness and analyzed for DNA content by FCM (Becton, Dickinson \& Co.), and populations of $G_{0} / G_{1}, S$, and $G_{2} / M$ were quantified using FlowJo software as previously described (14).
Detection of Bcl-2, Bax, Procaspase-3 and P-gp expression by western blotting. EC109 and EC109/Taxol cells were washed with ice-cold PBS and collected in ice-cold PBS. Thereafter the cell extracts were prepared in RIPA buffer (50 mM Tris- $\mathrm{HCl}, \mathrm{pH} 7.5,150 \mathrm{mM} \mathrm{NaCl}, 0.25 \%$ sodium deoxycholate, $0.1 \%$ Nonidet P-40, $0.1 \%$ Triton X-100) with the proteinase inhibitor cocktail from Sigma for $10 \mathrm{~min}$ and debris was removed by centrifugation at $15,000 \mathrm{rpm}$ for $7 \mathrm{~min}$ at $4^{\circ} \mathrm{C}$. The protein content in the cell lysates was determined using a BCA protein-assay kit. Cell lysates were boiled with gel-loading buffer for $5 \mathrm{~min}$ at $100^{\circ} \mathrm{C}$, and electrophoresed with 10\% SDS-polyacrylamide gel electrophoresis (PAGE). Proteins were transferred to nitrocellulose (NC) membranes. The membranes were blocked with a solution containing $5 \%$ skim milk and incubated at room temperature for $2 \mathrm{~h}$, then incubated overnight at $4{ }^{\circ} \mathrm{C}$ with each of the following antibodies: anti-Bcl-2 antibody (1:500), anti-Bax antibody 1:1000), anti-Procaspase-3 antibody (1:1000) and anti-P-gp antibody (1:200). After washing the membrane with PBST (PBS, $0.05 \%$ Tween-20) three times (10 min each), the blots were subsequently incubated with goat anti-mouse or anti-rabbit IgG-HRP secondary antibody (1:10000) at $37^{\circ} \mathrm{C}$ for $2 \mathrm{~h}$. Finally the blots were washed in PBST followed by two washes in PBS (10 min each). ECL was added to the membrane, which was developed and fixed for $3 \mathrm{~min}$. The antibody-reactive bands were revealed by enhanced chemiluminescence substrate and were exposed on Kodak radiographic film.

Rhodamine 123 accumulation and efflux assay. P-gp function was analyzed by the Rh123 assay. Intracellular retention of Rh123 was determined by flow cytometry as a functional index of P-gp activity (15). Cells were plated in 6-well plates in a concentration of $1 \times 10^{5} / \mathrm{ml}$ in $2 \mathrm{ml}$ per well and cultured for at $37^{\circ} \mathrm{C}$ in an atmosphere containing $5 \% \mathrm{CO}_{2}$. After an incubation of $24 \mathrm{~h}, \mathrm{Rh} 123$ was added to a final concentration of $1 \mu \mathrm{g} /$ $\mathrm{ml}$ for $30 \mathrm{~min}$ at $37^{\circ} \mathrm{C}$. Cells were harvested with trypsin after two washes with ice-cold PBS. After cell centrifugation, cells were resuspended rapidly with $300 \mu \mathrm{l}$ PBS and immediately used for flow cytometric analysis of rhodamine fluorescence at an excitation wavelength of $488 \mathrm{~nm}$ and an emission wavelength of $530 \mathrm{~nm}$.

To evaluate Rh123 retention, the cells were further incubated in Rh123-free incubation medium for $30 \mathrm{~min}$ at $37^{\circ} \mathrm{C}$. After twice washes with ice-cold PBS, mean fluorescence intensity (MFI) was determined. Non-specific binding of the drugs to the cells was measured by adding ice-cold drugcontaining medium to the cells and then washing immediately (16). The retention (\%) is the percentage of the retained fluorescence divided by the accumulated fluorescence of the cells (17).

In vivo solid tumor studies. EC109 and EC109/Taxol cells were harvested by trypsinization, washed, resuspended in sterilized normal saline (NS), then $0.2 \mathrm{ml}$ of NS with cells $\left(1.0 \times 10^{7}\right)$ were inoculated subcutaneously into the right armpit region of the mice to initiate tumor growth $(18,19)$. The tumors were allowed to reach an average size of $100-150 \mathrm{~mm}^{3}$ (as estimated by vernier caliper measurement), then the mice bearing EC109 cells (EC109-bearing mice) were randomly assigned 
A

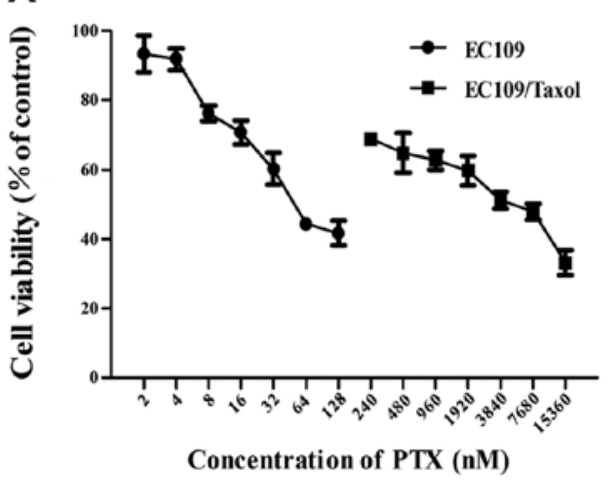

C

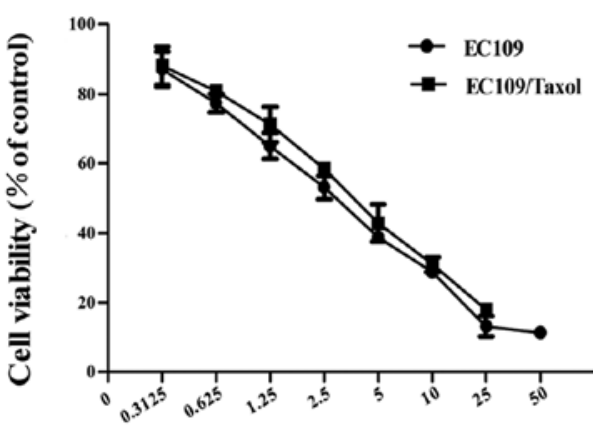

Concentration of CDDP $(\mu \mathrm{g} / \mathrm{ml})$

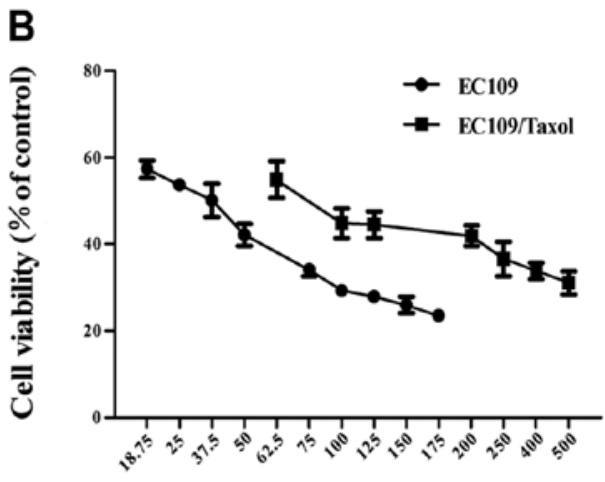

Concentration of 5-FU $(\mu \mathrm{g} / \mathrm{ml})$

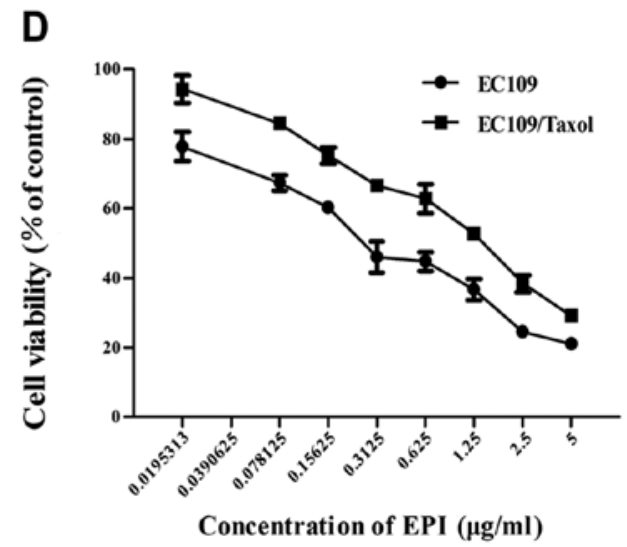

Figure 1. EC109 and EC109/Taxol cells survival curves with PTX, 5-fluorouracil (5-FU), cisplatin (CDDP) and epirubicin (EPI) treatments. The cells were cultured with seven or eight different concentrations of each drug for $48 \mathrm{~h}$. Cell viability was evaluated by MTT assay. IC50 values for the drugs were calculated by SPSS 17.0. Data represent means \pm standard deviation (SD) of at least triplicate determinations.

to two groups, each containing five mice, and administered with different formulations by tail intravenous injection every 3 days for a total of 21 days. Drugs were given to the mice at an optimal dose, based on preliminary experiments. Group 1 was treated with NS, group 2 was treated with PTX $(8 \mathrm{mg} / \mathrm{kg}$ of body weight). The mice bearing EC109/Taxol cells (EC109/ Taxol-bearing mice) were randomly assigned to two groups containing five mice each and received the same regimens as EC109-bearing mice. At the end of the treatment, mice were sacrificed by cervical vertebra dislocation, and tumors were dissected and weighed. During this period, the body weights of the animals were recorded every 3 days and tumors sizes were measured by determining two perpendicular dimensions at the same time. Then the volume (V) of each tumor was calculated using the following formula:

$$
\mathrm{V}=\mathrm{a} \times \mathrm{b}^{2} \times 1 / 2
$$

where length (a, mm) is the longest diameter and width (b, $\mathrm{mm}$ ) is the shortest diameter perpendicular to length respectively $(20,21)$. Calculated tumor volumes were expressed in percentages as relative tumor volume (RTV) from the equation (17):

$$
\mathrm{RTV}=\mathrm{V}_{\mathrm{n}} / \mathrm{V}_{0}
$$

where $V_{n}$ is the tumor volume at day $n$ of treatment and $V_{0}$ represents the initial tumor volume at the onset of treatment. The criterion of antitumor activity was tumor growth inhibi- tion. The rate of inhibition (IR) was calculated according to the formula (22):

$$
\operatorname{IR}(\%)=1-\frac{(\text { Mean of tumor weight of the treated group) }}{\text { (Mean of tumor weight of the control group) }} \times 100 \%
$$

Statistical analysis. Each experiment was performed at least in triplicate, and the measurements were performed in three independent experiments. Data are expressed as means \pm standard deviation (SD). Continuous variables were analyzed using Student's t-test. A value of $\mathrm{p}<0.05$ was considered statistically significant, and if $\mathrm{p}<0.01$, it was noted. All analyses were performed using SPSS17.0 statistical packages.

\section{Results}

Establishment and phenotype of the resistant cell line, EC109/ Taxol cells. EC109/Taxol cells were generated in vitro by intermittent exposure human EC109 to a high concentration of PTX with time-stepwise increment for 6 months. EC109/ Taxol cells were then cultured in drug-free medium for at least 1 month. The IC50 PTX values in EC109 and EC109/Taxol cells were $0.051 \pm 0.001$ and $3.426 \pm 0.074 \mu \mathrm{g} / \mathrm{ml}$, respectively. EC109/Taxol cells were 67.175-fold more resistant to PTX than the parent cells (Fig. 1A and Table I). We also compared the cross-resistance values to 5-FU, CDDP and EPI between the parent and PTX-resistant cells (Fig. 1B-D and Table I). EC109/Taxol cell line was not only resistant to PTX, but also 
Table I. Multidrug resistant phenotype of EC109/Taxol cells compared to its parental EC109 cells.

\begin{tabular}{lrrrrr}
\hline & \multicolumn{2}{c}{ IC50 $(\text { mean } \pm \mathrm{SD}, \mu \mathrm{g} / \mathrm{ml})^{\mathrm{a}}$} & & \\
\cline { 2 - 4 } Drugs & \multicolumn{1}{c}{ EC109 } & EC109/Taxol & RI $^{\mathrm{b}}$ & p-value $^{\mathrm{c}}$ \\
\hline PTX & $0.051 \pm 0.001$ & $3.426 \pm 0.074$ & 67.175 & $<0.001$ \\
5-FU & $32.219 \pm 1.450$ & $80.533 \pm 3.893$ & 2.500 & $<0.001$ \\
CDDP & $3.025 \pm 0.172$ & $3.603 \pm 0.113$ & 1.191 & $<0.05$ \\
EPI & $0.351 \pm 0.023$ & $1.224 \pm 0.050$ & 3.491 & $<0.001$ \\
\hline
\end{tabular}

PTX, Paclitaxel; 5-FU, 5-fluorouracil; CDDP, cisplatin; EPI, epirubicin; IC50, 50\% inhibitory concentration; SD, standard variation; $\mathrm{RI}$, resistance index; ${ }^{\mathrm{a}}$ The IC50 values are presented as mean $\pm \mathrm{SD}$ of

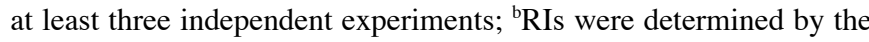
ratio of IC50 values of EC109/Taxol to that of EC109 cells; ${ }^{c}$ p-values were determined by Student's t-test between the IC50 values of both cell lines. EC109 and EC109/Taxol cells were exposed to indicated concentrations of PTX, 5-FU, CDDP and EPI for $48 \mathrm{~h}$ and determined using the MTT assay. The IC50 values were calculated.

cross-resistant to 5-FU, CDDP and EPI, to which they were not exposed, indicating it was a multidrug-resistant cell line.
Apoptosis assay using Hoechst 33258 staining and FCM. Under the inverted microscope, both EC109 and EC109/Taxol cells grew adherent to the bottom and showed epithelial-like shape as polygon. Microscopic observation found EC109 cells were relatively uniform in size and shape in monolayer culture. However, EC109/Taxol cells tended to grow in clusters, showed irregular shape and varied in size, with both giant and small cells. Both EC109 and EC109/Taxol cells were treated with $100 \mathrm{nM}$ PTX for $24 \mathrm{~h}$ to determine the effects of PTX on apoptosis, results showed the both types of cells underwent marked morphological changes upon treatment with PTX compared with the untreated control cells. As observed by the inverted microscope, the cells exhibited discrete morphological differences only after $24 \mathrm{~h}$ of infection in comparison to control cells. It could be seen that $100 \mathrm{nM}$ PTX infection caused reduced EC109 cell number, smaller cell sizes, breakage into smaller pieces and detaching from the plate, compared with the EC109/Taxol cells treated with PTX (Fig. 2A). In addition, the cells were stained with Hoechst 33258 and the apoptotic cells were evaluated morphologically by fluorescence microscopy. As displayed in Fig. 2A, the nuclei of the untreated EC109 and EC109/Taxol cells were stained homogeneously blue, while in the group treated with PTX, cells had bright chromatin condensation and nuclear fragmentation which are typical of apoptosis. Compared to EC109/Taxol cells, EC109 cells
A

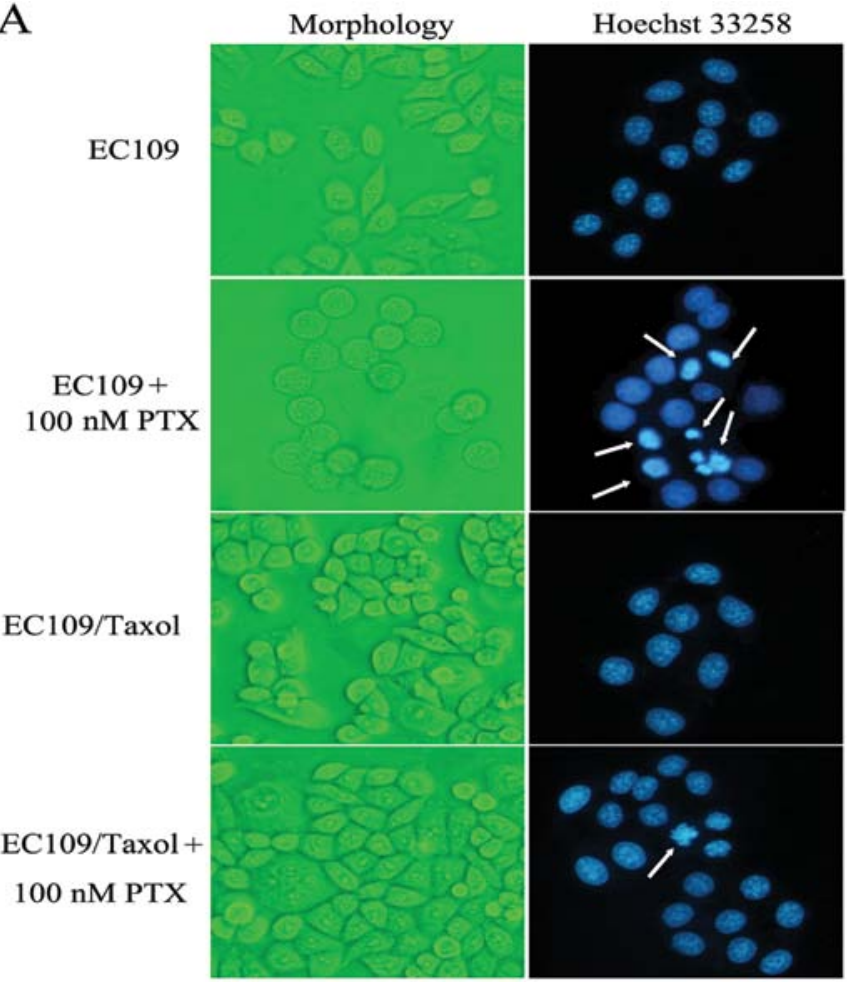

B

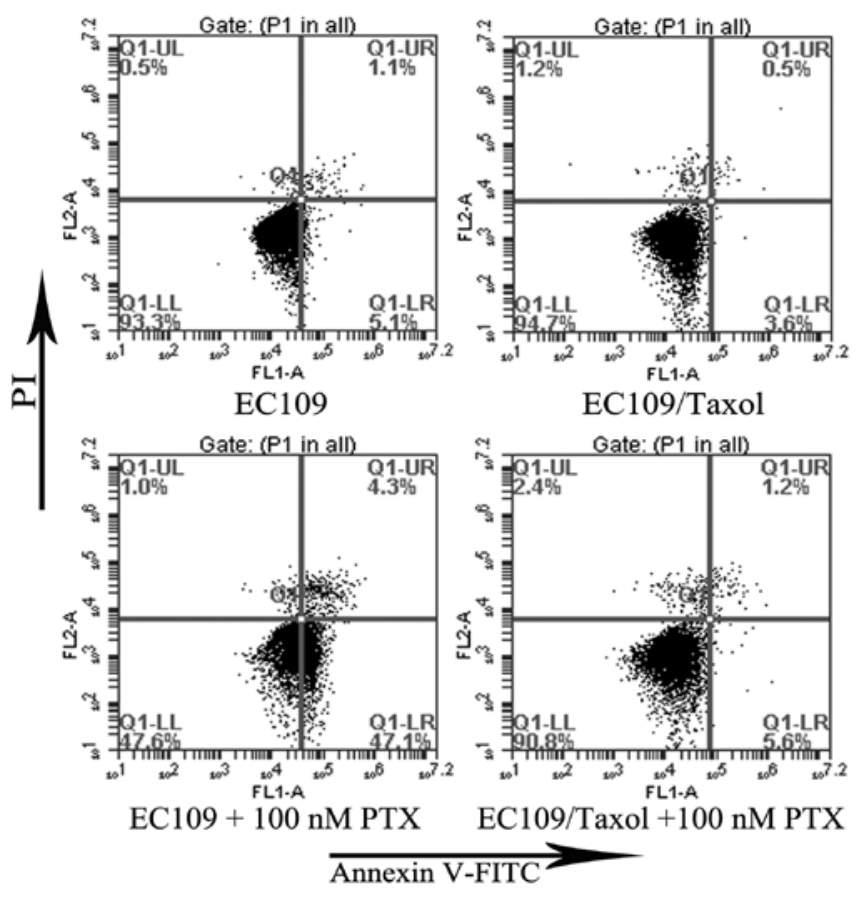

Figure 2. Morphology of EC109 and EC109/Taxol cells and PTX induced apoptosis in both cell types by Hoechst 33258 staining and FCM. (A) Morphological characteristics were determined using an inverted microscope at original magnification of x200. EC109 cells were relatively uniform in size and shape in monolayer culture, while EC109/Taxol cells showed irregular shape and size, with some giant and some small cells. Morphological alterations of EC109 and EC109/Taxol cells treated with $100 \mathrm{nM}$ PTX was evaluated by using an invert microscope with x200 magnification. The EC109 cells became small in size, broke into smaller pieces and detached from the plate compared with the EC109/Taxol cells treated with PTX. An apoptosis assay was measured by Hoechst 33258 staining and analyzed under a fluorescent microscope with x200 magnification. Nuclei were stained weak homogeneous blue in the normal cells, and bright chromatin condensation and nuclear fragmentation (white arrow) were found in the apoptotic cells. Compared to EC109/Taxol cells, EC109 cells treated with PTX showed significantly increased frequency of apoptosis with its typical morphologic features. B: The apoptotic status was evaluated by Annexin V-FITC/PI

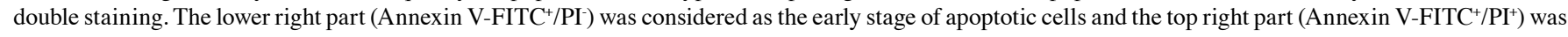
considered as the late stage of apoptotic cells. The lower left part (Annexin V-FITC-/PI') was considered as viable cells and the upper left part (Annexin V-FITC ${ }^{-}$ $\mathrm{PI}^{+}$) was considered as necrotic cells. The results demonstrated that EC109/Taxol cells were more resistant to PTX than EC109 cells. 


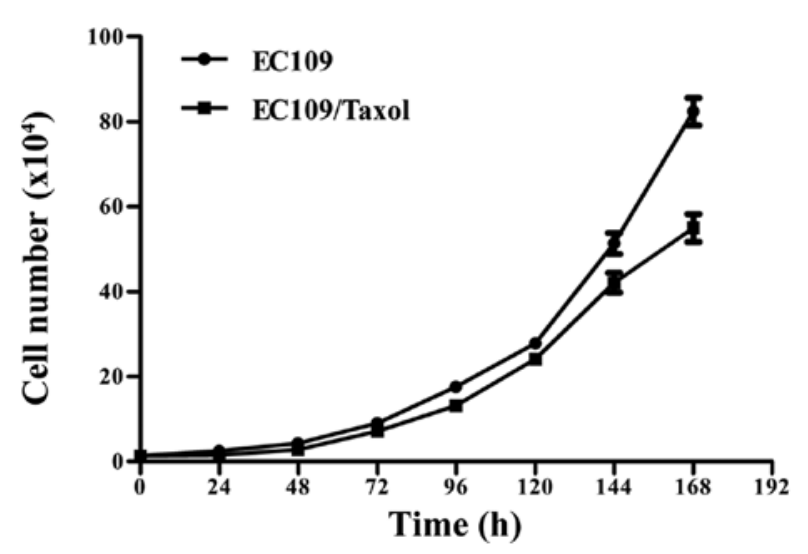

Figure 3. Growth curves of EC109 and EC109/Taxol cells. The cell growth curve was plotted with culture time as the $\mathrm{X}$ axis and the average cell counts/ per day as the Y axis. The EC109/Taxol cells began to grow slower than EC109 cells following 48 hours of incubation, and the difference of growth speed became significant after $96 \mathrm{~h}(\mathrm{p}<0.05)$.

treated with PTX showed significantly increased frequency of apoptosis with its typical morphologic features.

To quantify PTX-induced apoptotic death of EC109 and EC109/Taxol cells, Annexin V-FITC and PI staining were done followed by FCM. Apoptosis cells were determined by Annexin V-FITC-positive and PI-negative cells (Annexin $\mathrm{V}-F I T C^{+} / \mathrm{PI}^{-}$). The natural cell apoptosis rates were $5.1 \pm 0.84 \%$ and $3.6 \pm 0.64 \%$ in EC109 and EC109/Taxol cells as shown in Fig. 2B. After treated with $100 \mathrm{nM}$ of PTX for $24 \mathrm{~h}$, the cell apoptosis rates increased to $(47.1 \pm 3.82) \%$ in EC109 cells, and to (5.6 \pm 0.45$) \%$ in EC109/Taxol cells. Therefore, the results demonstrated that EC109/Taxol cells were more resistant to PTX than EC109 cells ( $<<0.01)$.

Growth curves and the doubling time (Td). The growth curves of EC109/Taxol cells and their parental cells are shown in Fig. 3. From $48 \mathrm{~h}$ of incubation, the EC109/Taxol cells began to grow slower compared with EC109 and the difference of growth speed became significant after $96 \mathrm{~h}(\mathrm{p}<0.05)$. According to the cell growth curves, the Td of EC109 and EC109/Taxol cells was $28.57 \pm 0.12 \mathrm{~h}$ and $31.38 \pm 0.39 \mathrm{~h}$, respectively $(\mathrm{p}<0.05)$.
Table II. The colony formation rate of EC109 and EC109/ Taxol cells.

\begin{tabular}{lcc}
\hline Cells & Colony formation rate (\%) & No. \\
\hline EC109 & $94.13 \pm 3.07$ & 3 \\
EC109/Taxol & $53.30 \pm 4.07^{\mathrm{a}}$ & 3
\end{tabular}

Results are displayed as mean $\pm \mathrm{SD}(\mathrm{n}=3)$. ${ }^{\mathrm{a}}$ Compared with the parental cells EC109, the difference is significant with $\mathrm{p}<0.001$.

Colony efficiency. The EC109/Taxol cells had less potential to form colonies. The number of EC109/Taxol cell colonies was less and their size was smaller compared to the wells with EC109 cells (Fig. 4). The colony formation rate of EC109/ Taxol was $53.30 \pm 4.07 \%$, which was significantly decreased compared to a colony formation rate of $94.13 \pm 3.07 \%$ for EC109 after a culture of 7 days $(p<0.001)($ Table II).

Determination of cell cycle distribution by FCM. FCM showed the proportion of cells in $\mathrm{G}_{0} / \mathrm{G}_{1}, \mathrm{~S}$ and $\mathrm{G}_{2} / \mathrm{M}$ phases were 47.96, 26.48 and $25.56 \%$ for EC109; and 55.51, 32.90 and $11.59 \%$ for EC109/Taxol, respectively. The EC109/Taxol cells exhibited longer $G_{0} / G_{1}$ and $S$ phases with a concomitantly shorter $\mathrm{G}_{2} / \mathrm{M}$ phase in cycle distribution than EC109 cells (Fig. 5).

Western blot analysis. The expression of the different partners studied in the present study was evaluated by western blotting. The expression of Bcl-2, Bax, Procaspase-3 and P-gp were detected in both EC109 and EC109/Taxol cells (Fig. 6A) to further characterize the resistance and its mechanisms. To look for statistically significant differences, Bcl-2/GAPDH, Bax/GAPDH, Procaspase-3/GAPDH and P-gp/GAPDH ratio were calculated and a t-test was performed, results showed that Bcl-2, Bax, Procaspase-3 and P-gp protein expression ratio of EC109/Taxol to EC109 cells were $1.283(\mathrm{p}<0.05), 0.864(\mathrm{p}<0.05), 1.348(\mathrm{p}<0.01)$ and $2.170(\mathrm{p}<0.01)$, respectively (Fig. 6B). Western blot analysis
A

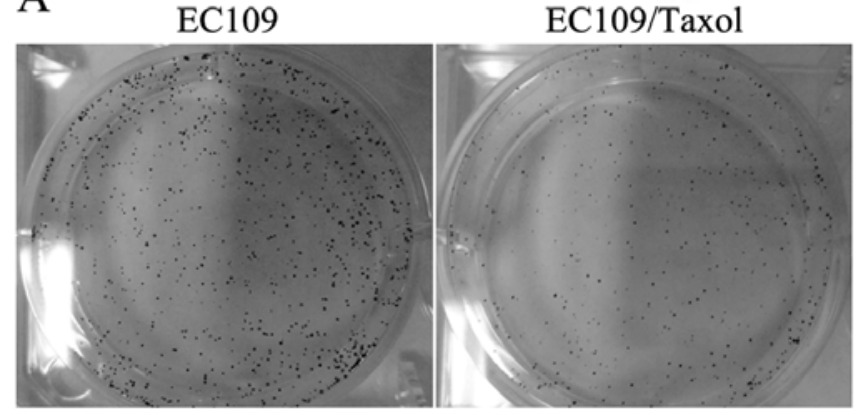

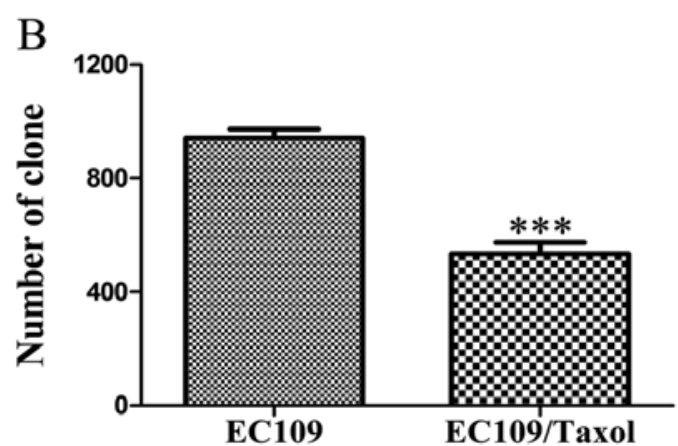

Figure 4. The colony formation of EC109 and EC109/Taxol cells. Cells were incubated at $37^{\circ} \mathrm{C}$ in a humidified air atmosphere containing $5 \% \mathrm{CO}_{2}$ incubator for 7 days. (A) A representative result under low magnification, showing that the EC109/Taxol cells clones grew significantly more colonies than the EC109 cell clones. (B) The average number of colonies and SD for the two groups were calculated based on three independent experiments. The EC109/Taxol cells formed significantly more colonies compared to the EC109 cells $(* * * 00001)$. 

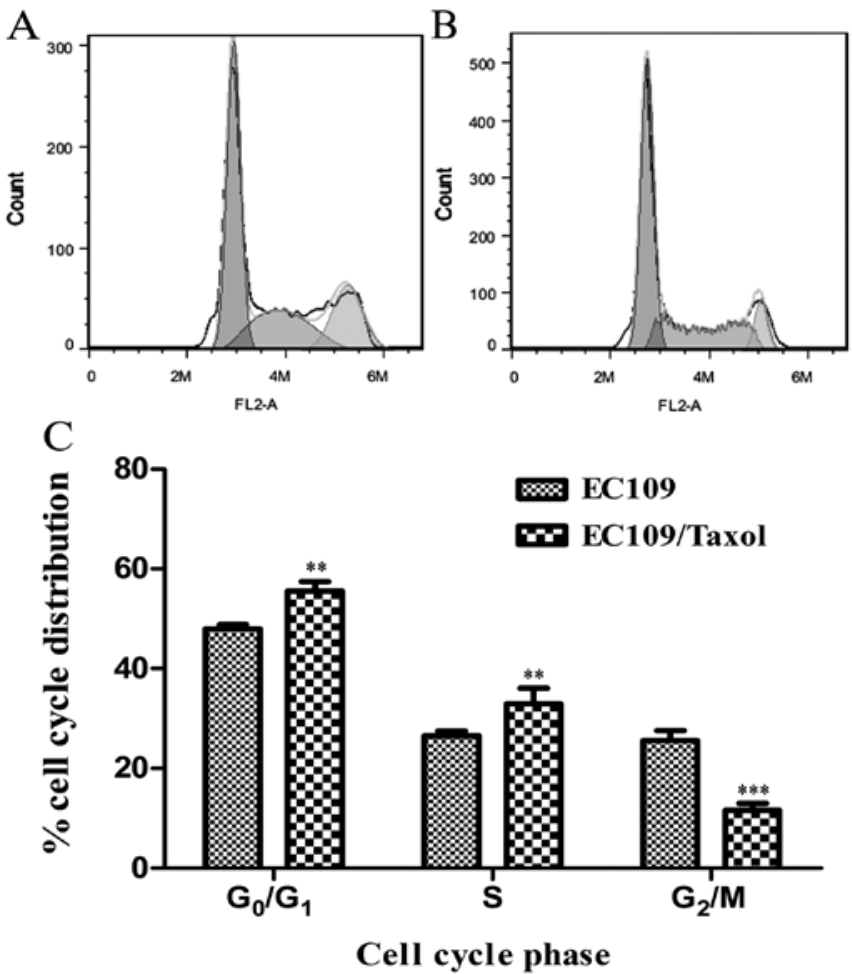

Figure 5. Cell cycle distribution of EC109 and EC109/Taxol was revealed by flow cytometry. (A) EC109; (B) EC109/Taxol; (C) Flow cytometry data displayed in bar format. The proportion of EC109/Taxol cells in the $\mathrm{G}_{0} / \mathrm{G}_{1}$ and $\mathrm{S}$ phases were increased significantly compared with EC109 cells $(* \mathrm{*} p<0.01)$ with a concomitant reduction in $\mathrm{G}_{2} / \mathrm{M}$ phase significantly $\left.{ }^{* * *} \mathrm{p}<0.001\right)$

confirmed that the Bcl-2, Procaspase-3 and P-gp protein expressions were efficiently higher in the EC109/Taxol than in the EC109, while the Bax expression was lower than in the parental cells $(\mathrm{p}<0.01)$.

Rhodamine 123 accumulation and efflux assay. Intracellular Rh123-associated MFI in EC109 and EC109/CDDP cells was employed to study the P-gp function. Rh123 was used as a molecular probe for a functional assay. Since this fluorescent dye is considered to be a relatively specific substrate of P-gp, reduced retention of Rh123 in the cells gives an indication of the function of P-gp (23). Rh123 retention was evaluated after accumulation for $30 \mathrm{~min}$ and $30 \mathrm{~min}$ efflux in dye-free medium. As demonstrated in Fig. 7, the EC109/Taxol cells significantly reduced the retention of Rh123 compared with the EC109 cells $(\mathrm{p}<0.05)$. The Rh123 retention in the EC109/ Taxol cells correlated with the relative P-gp expression.

Characterization of resistance in vivo. Resistance of parental EC109 and highly PTX-resistant EC109/Taxol cells were detected in vivo by use of two nude mouse xenograft models (EC109-bearing mice and EC109/Taxol-bearing mice). The two xenograft models achieved a volume of more than $100 \mathrm{~mm}^{3}$ on day 3-4 or 5-6 and tumor incidence was $100 \%$ after subcutaneous implantation with $10^{7}$ of each cell type. Tumor growth presented by RTV was measured and calculated as described in the Materials and methods. Tumor growth curves were constructed by plotting tumor volumes against time (Fig. 8B). Tumor volumes in EC109-bearing
A
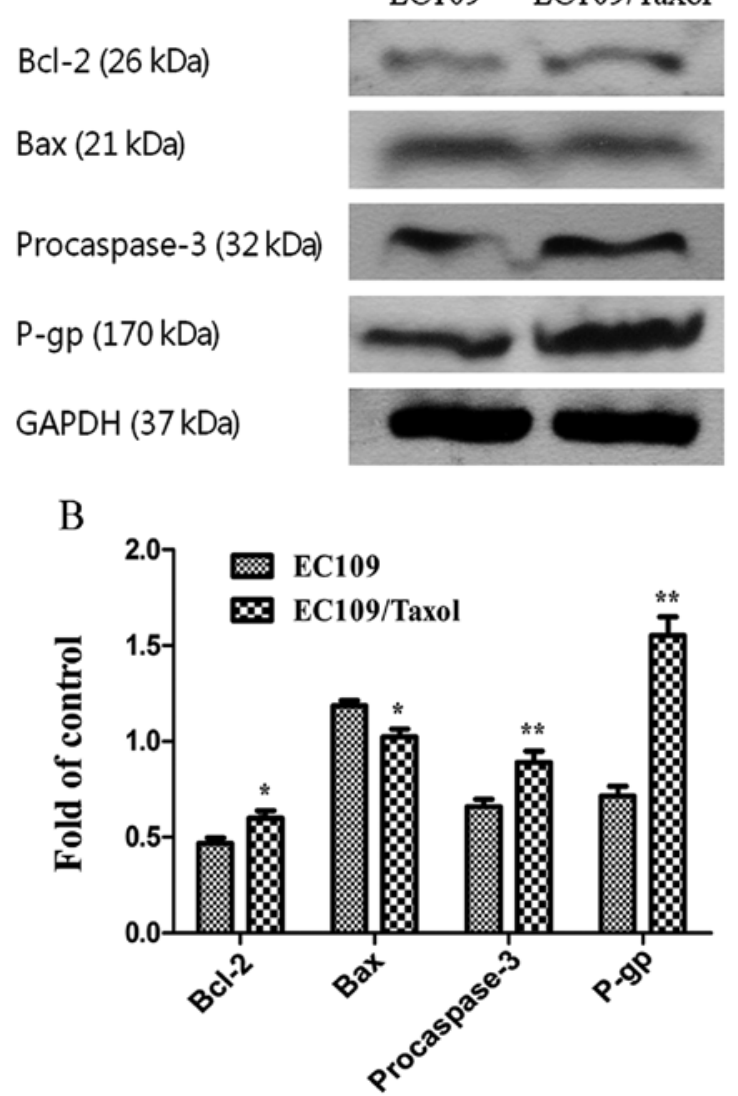

Figure 6. Differential expressed proteins Bcl-2, Bax, Procaspase-3 and P-gp identified by proteomic approach were validated by western blot analysis as described in the Materials and methods section. (A) Western blotting image of Bcl-2, Bax, Procaspase-3, P-gp and GAPDH in EC109 and EC109/Taxol cells. (B) Protein expression levels of Bcl-2, Bax, Procaspase-3 and P-gp after normalization relative to GAPDH. ${ }^{*} \mathrm{p}<0.05 ;{ }^{* *} \mathrm{p}<0.01$.

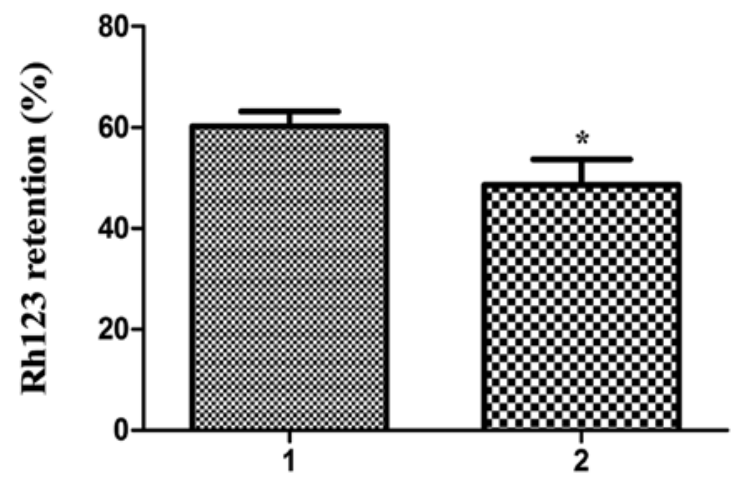

Figure 7. P-gp function-dependent reduction of Rh123 retention (\%). Rh123 retention was evaluated after accumulation for $30 \mathrm{~min}$ and $30 \mathrm{~min}$ efflux in dye-free medium. The retention $(\%)$ is the percentage of the retained fluorescence divided by the accumulated fluorescence of the cells. A rapid decrease of intracellular Rh123 level was observed in EC109/Taxol cells after incubation in Rh123-free medium for $30 \mathrm{~min}$. 1, EC109 cells; 2, EC109/Taxol cells. "Compared with parental cells EC109, the difference is significant with $\mathrm{p}<0.05$.

mice and EC109/Taxol-bearing mice were decreased by treatment with PTX. Tumors formed from EC109/Taxol cells exhibited resistance to PTX compared to the tumors formed 
$\mathbf{A}$

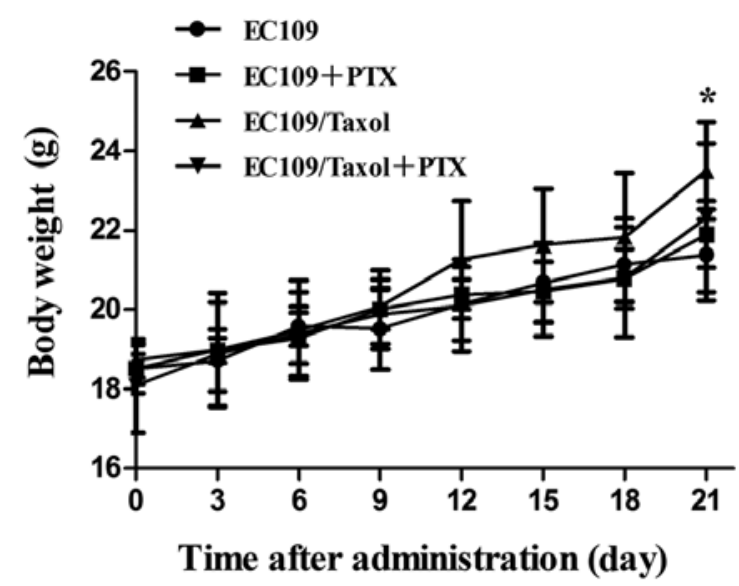

B

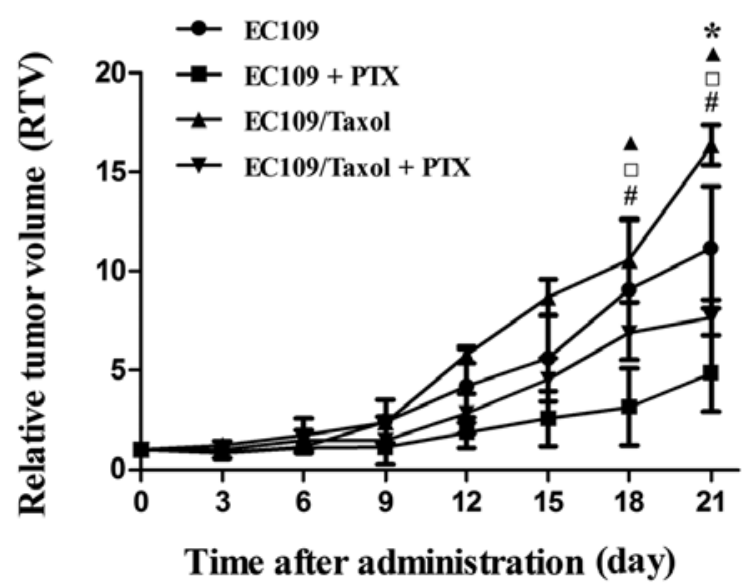

Figure 8. Inhibition effect of PTX in vivo. (A) Average body weight was measured every three day during the drug treatment. (B) Tumor growth curves were constructed by plotting tumor volumes against time. Volume of tumor in each mouse was measured every three day for 21 days. Tumor growth presented by RTV was measured and calculated as described in the Materials and methods section. " $\mathrm{p}<0.05$ represents that EC109-bearing mouse group is significantly different from EC109/Taxol-bearing mouse group; ${ }^{\wedge} \mathrm{p}<0.05$ represents that EC109-bearing mouse group is significantly different from EC109-bearing mouse group treated with PTX; ${ }^{\square} \mathrm{p}<0.05$ represents that EC109/Taxol-bearing mouse group is significantly different from EC109/Taxol-bearing mouse group treated with PTX; ${ }^{\#}$ p $<0.05$ represents that EC109/Taxol-bearing mouse group treated with PTX is significantly different from EC109-bearing mouse group treated with PTX. from EC109 cells. The IR values of single PTX treatment in the EC109-bearing mice or EC109/Taxol-bearing mice were 73.59 or 33.10 , as measured three weeks after the treatment (Table III). To monitor the toxicity of the treatment, the body weight of the nude mice were recorded. Neither in EC109bearing mice nor in EC109/Taxol-bearing mice did we see any significant body weight loss during drug administration, suggesting that this regimen was safe (Fig. 8A). Therefore, there was significant difference in the PTX resistance in the EC109/Taxol as compared to the parental EC109 using the nude mouse system.

\section{Discussion}

MDR is one of the major impediments for effective chemotherapy in cancer patients as cancer cells may become cross-resistant to a broad spectrum of chemotherapeutic agents after a single drug treatment $(24,25)$. The MDR phenotype of cancer cells might be intrinsic or acquired after chemotherapy treatment using cytotoxic agents (26). Therefore, it is essential to understand the multifunctional mechanisms in the development of resistance to cancer chemotherapy in order to improve the prognosis of cancer patients. It has been well acknowledged that a comprehensive understanding of possible molecular mechanisms and signal pathways involved MDR of EC could be useful to overcome MDR and improve the chemotherapeutic efficacy for EC patients. Based on these considerations, the establishment of drug-resistant cancer cell lines is crucial for studying the biological characteristics of resistant cells, the mechanisms of drug resistance and the methods to overcome it. In this study, we established a PTX-resistant EC109 cell line in vitro as model for investigating chemotherapy resistance by intermittent exposure of EC109 parent cells to a high concentration of PTX with time-stepwise increment. The intermittent exposure to high concentration of PTX was also integrated to imitate the treatment cycles patients received clinically. To our knowledge, this is the first report on the establishment of EC109/Taxol cell line with higher resistance.

In the process of induction, most of the cells were enlarged in cell volume, and many vacuoles appeared in the cytoplasm. The cells gradually died and floated. A few cells without drug treatment survived after a period of time, and resumed exponential growth. As a result, after an induction of 6 months a PTX-resistant EC109 cell line EC109/Taxol

Table III. Inhibition effect of PTX on tumor growth of EC109-bearing mice and EC109/Taxol-bearing mice.

\begin{tabular}{|c|c|c|c|c|}
\hline Group & Dosage (mg/kg) & Animal number (initial/final) & Tumor weight (g) & $\operatorname{IR}(\%)$ \\
\hline EC109 & - & $5 / 5$ & $1.34 \pm 0.27$ & - \\
\hline EC109+PTX & 8 & $5 / 5$ & $0.36 \pm 0.22^{\mathrm{a}}$ & 73.59 \\
\hline EC109/Taxol & - & $5 / 5$ & $0.85 \pm 0.50$ & - \\
\hline EC109/Taxol+PTX & 8 & $5 / 5$ & $0.57 \pm 0.48^{b}$ & 33.10 \\
\hline
\end{tabular}

Data are expressed as means \pm SD. ${ }^{a} \mathrm{p}<0.001$ vs. EC109 group. ${ }^{\mathrm{b}} \mathrm{p}<0.05$ vs. EC109/Taxol group. 
with a high RI of 67.175 was established with a typical MDR phenotype. Simultaneously, as compared with the parental EC109 cells, EC109/Taxol cells showed 2.500, 1.191 and 3.491 fold resistance to 5-FU, CDDP and EPI, respectively. This multidrug-resistant characteristic of EC109/Taxol cells might imply failure of chemotherapy combinations of PTX with 5-FU, CDDP and EPI in clinical practice. The establishment of multidrug-resistant cell line EC109/Taxol has provided a powerful tool for further study of the multidrug-resistant phenotypes.

Under the induction of chemotherapeutic drugs, tumor cells usually produce apoptotic tolerance $(27,28)$. Therefore, we further examined the apoptosis rate of EC109 and EC109/ Taxol cells induced by PTX through flow cytometry and Hoechst 33258 fluorescence staining. Our results indicated that the apoptosis rate in EC109/Taxol cells caused by PTX decreased significantly as compared with EC109 cells. The results corroborated that EC109/Taxol cells were more resistant to PTX than EC109 cells.

Compared to its parental cells, the most prominent feature of EC109/Taxol lies in the slower proliferation which has been verified by other MDR EC109 cell lines (29). In this study, EC109/Taxol had a doubling time of $31.38 \mathrm{~h}$, which was prolonged by $9.91 \%$ compares to the doubling time of $28.57 \mathrm{~h}$ for its parental cells. The difference in colony efficiency between EC109/Taxol and EC109 cells further confirmed a significant reduced proliferation of EC109/Taxol. This might be caused by the existence of non-cycling dormant cells. In addition, the proportion of EC109/Taxol cells in the $\mathrm{G}_{0} / \mathrm{G}_{1}$ and $\mathrm{S}$ phases was increased significantly compared with EC109 cells in corresponding phases. There is a critical balance between cell cycle arrest (promoting DNA repair and survival) and cell death following chemotherapy. In response to DNA damage, some genes will be activated or inactivated to induce cell cycle arrest in $\mathrm{G}_{1}$ phase in order to repair damaged DNA (30). Cell cycle-mediated drug resistance is best described as a relative insensitivity to a chemotherapeutic agent because of the position of the cells in the cell cycle. A higher proportion of EC109/Taxol cells were in the $G_{0} / G_{1}$ phase, possibly indicating an enhanced capacity in DNA damage repair, which could be considered as a mechanism of drug resistance. The redistribution of cell cycles might be attributed to adaptive response of EC109 cells to cytotoxicity effects to survive, and might lead to cellular escape from the cytotoxicity of anticancer drugs and the development of MDR.

Furthermore, the mechanism of MDR was complicated, including increased drug efflux, altered anticancer drug targets, decreased drug absorption, reduced drug activation, enhanced DNA damage repair capacity, inhibited cell apoptosis and so on (31-33). Among them, increased efflux of cytotoxic drugs out of cancer cells was the most common phenomenon of weakening the effects of anticancer drugs (34). The enhanced efflux pump activity was attributed to the overexpression of membrane transport proteins that belong to the ATP-binding cassette (ABC) transporter superfamily, such as multidrug resistance gene 1 (MDR1), which encodes P-gp, multidrug resistance-associated protein (MRP) 1, lung resistance protein (LRP) and the breast cancer resistance protein (BCRP) (35). P-gp belongs to the superfamily of transporter proteins containing an ATP-binding cassette. It is thought to function as a broad substrate of ATP-dependent pump to reduce intracellular drug concentration below a cell-killing threshold (36-38). The selection of cancer cells in culture with natural-product anticancer drugs, such as PTX, doxorubicin, or vinbblastine, frequently results in multidrug resistance that is due to expression of the ABC transporter P-gp $(39,40)$. Therefore, we used Western blot to detect the expression level of P-gp in EC109 and EC109/Taxol cells. Our results showed that in PTX resistant cell line EC109/Taxol, the expression of P-gp were significantly increased. Rh123 accumulation and efflux assay was employed to check the function of P-gp. The EC109/Taxol cells significantly reduced the retention of Rh123 compared with the EC109 cells, which indicated that the activity of P-gp was remarkedly enhanced in EC109/Taxol cells. Western blot and P-gp function assay results suggested that the activity of P-gp might play an important role in the acquired MDR of EC109/Taxol.

Tumor cells accessed the multidrug resistance while the ability of anti-apoptosis induced by chemotherapeutic drugs enhanced, indicating multidrug resistance of tumor cells was closely related to apoptosis inhibition (41). The Bcl-2 and caspase families are considered to be the most important proteins regulating apoptosis, which can be divided into two types: anti-apoptotic and pro-apoptotic proteins (42). Dominant in the two families, Bcl-2 and Bcl-xL are anti-apoptotic protein. In contrast, Bax, cleaved caspase-3, caspase- 8 and caspase- 9 are pro-apoptotic proteins. Some Bcl-2 family proteins have been considered to be the crucial switch of the apoptotic process, and represents a critical checkpoint within apoptotic pathways (43). Moreover, the initiation of all intracellular events seems to be connected with the activation of specific proteases called caspases. In this process, caspase- 3 seems to play a role in the execution of apoptosis $(44,45)$. The increase in caspase-3 activation is synchronized with an alteration of the Bcl-2 family, such as an increased expression of pro-apoptotic protein Bax and a decreased expression of anti-apoptotic protein Bcl-2 $(45,46)$. The ratio of $\mathrm{Bcl}-2 / \mathrm{Bax}$ is a critical determinant for cell apoptosis. The dysregulation of the Bcl-2 family was proved to induce the destruction of mitochondrial membrane, which was accompanied by the release of intramembranous proteins into the cytosol, such as cyt $\mathrm{C}$ and other apoptosis-inducing factors, and subsequently induces activation of the caspase cascade (47). Therefore, the expression of Bcl-2, Bax and Procaspase-3 was analyzed in this study. Our results showed that in PTX resistant cell line EC109/Taxol, the expression of Bcl-2 and Procaspase-3 were significantly increased but the expression of Bax was reduced. Additionally, the resistance to apoptosis in the LR73-DDR1 cells could be reversed using the pharmacological inhibitor of P-gp function, verapamil (48). These studies were the first to demonstrate convincingly an anti-apoptotic function for P-gp. P-gp can inhibit cleavage and activation of caspase- 3 and caspase- 8 thereby confers resistance to caspase-dependent apoptotic stimuli (49-52). The results suggest that antiapoptosis induced by chemotherapeutic drugs is also involved in MDR mechanisms of EC109/Taxol cells.

Since almost all investigations have been performed in in vitro systems, it remains unclear whether the resistance phenotypes could be maintained in vivo as well. Thus, we 
decided to perform the PTX sensitivity studies in vivo. The two xenograft models achieved a volume of more than $100 \mathrm{~mm}^{3}$ on day 3-4 or 5-6 and tumors incidence was $100 \%$ after subcutaneous implantation with $10^{7}$ of each cell type. Compared with EC109-bearing mice, the EC109/Taxol-bearing mice were more resistant to PTX. Consequently, the EC109/Taxol cell resistance phenotypes were maintained in in vivo systems as well.

In conclusion, this study has established a new human esophageal squamous carcinoma EC109/Taxol, which shows cross-resistance to several drugs of different structures and mechanisms for the first time. The newly established PTX-resistant cell line of EC109 will provide clinically relevant tools to investigate how to overcome drug resistance and elucidate possible mechanisms of acquired MDR.

\section{References}

1. Ferlay J, Shin HR, Bray F, Forman D, Mathers C and Parkin DM: Estimates of worldwide burden of cancer in 2008: GLOBOCAN 2008. Int J Cancer 127: 2893-2917, 2010.

2. Jemal A, Siegel R, Ward E, Hao Y, Xu J and Thun MJ: Cancer statistics, 2009. CA Cancer J Clin 59: 225-249, 2009.

3. Lepage C, Rachet B, Jooste V, Faivre J and Coleman MP: Continuing rapid increase in esophageal adenocarcinoma in England and Wales. Am J Gastroenterol 103: 2694-2699, 2008.

4. Kato $\mathrm{H}$ and Nakajima M: Treatments for esophageal cancer: a review. Gen Thorac Cardiovasc Surg 61: 330-335, 2013.

5. Pohl H and Welch HG: The role of overdiagnosis and reclassification in the marked increase of esophageal adenocarcinoma incidence. J Natl Cancer Inst 97: 142-146, 2005.

6. Pennathur A, Farkas A, Krasinskas AM, et al: Esophagectomy for T1 esophageal cancer: outcomes in 100 patients and implications for endoscopic therapy. Ann Thorac Surg 87: 1048-1055, 2009.

7. Siewert JR and Ott K: Are squamous and adenocarcinomas of the esophagus the same disease? Semin Radiat Oncol 17: 38-44, 2007.

8. Harris AL and Hochhauser D: Mechanisms of multidrug resistance in cancer treatment. Acta Oncol 31: 205-213, 1992.

9. Tsubaki M, Satou T, Itoh T, et al: Overexpression of MDR1 and survivin, and decreased Bim expression mediate multidrugresistance in multiple myeloma cells. Leuk Res 36: 1315-1322, 2012.

10. Crown $\mathrm{J}$ and $\mathrm{O}$ 'Leary M: The taxanes: an update. Lancet 355: 1176-1178, 2000.

11. Parness J and Horwitz SB: Taxol binds to polymerized tubulin in vitro. J Cell Biol 91: 479-487, 1981.

12. Schalhorn B: Paclitaxel (taxol) - a cytostatic drug with a new kind of mechanism of action. Med Klin (Suppl) 2: 4-6, 1993.

13. Shen XJ, Wang HB, Ma XQ and Chen JH: $\beta, \beta$-Dimethylacrylshikonin induces mitochondria dependent apoptosis through ERK pathway in human gastric cancer SGC-7901 cells. PLoS One 7: e41773, 2012.

14. Qiu XB, Schonthal AH and Cadenas E: Anticancer quinones induce $\mathrm{pRb}$-preventable $\mathrm{G} 2 / \mathrm{M}$ cell cycle arrest and apoptosis. Free Radic Biol Med 24: 848-854, 1998.

15. Petriz $\mathbf{J}$ and Garcia-Lopez J: Flow cytometric analysis of P-glycoprotein function using rhodamine 123. Leukemia 11: 1124-1130, 1997.

16. Huang C, Xu D, Xia Q, Wang P, Rong C and Su Y: Reversal of P-glycoprotein-mediated multidrug resistance of human hepatic cancer cells by Astragaloside II. J Pharm Pharmacol 64: 1741-1750, 2012.

17. Uchiyama-Kokubu $\mathrm{N}$ and Watanabe $\mathrm{T}$ : Establishment and characterization of adriamycin-resistant human colorectal adenocarcinoma HCT-15 cell lines with multidrug resistance. Anticancer Drugs 12: 769-779, 2001.

18. Jin Y, Li J, Rong LF, Li YH, Guo L and Xu SY: Antihepatocarcinoma effects of 5-fluorouracil encapsulated by galactosylceramide liposomes in vivo and in vitro. World $\mathbf{J}$ Gastroenterol 11: 2643-2646, 2005.
19. Chen XG, Liu HY, Lei XH, et al: Cancer chemopreventive and therapeutic activities of red ginseng. J Ethnopharmacol 60: 71-78, 1998.

20. Tian QE, Li HD, Yan M, Cai HL, Tan QY and Zhang WY: Astragalus polysaccharides can regulate cytokine and P-glycoprotein expression in $\mathrm{H} 22$ tumor-bearing mice. World J Gastroenterol 18: 7079-7086, 2012.

21. Wacheck V and Zangemeister-Wittke U: Antisense molecules for targeted cancer therapy. Crit Rev Oncol Hematol 59: 65-73, 2006.

22. Zhou Q, Li Y, Jin J, et al: Lx2-32c, a novel taxane derivative, exerts anti-resistance activity by initiating intrinsic apoptosis pathway in vitro and inhibits the growth of resistant tumor in vivo. Biol Pharm Bull 35: 2170-2179, 2012.

23. Feller N, Kuiper CM, Lankelma J, et al: Functional detection of MDR1/P170 and MRP/P190-mediated multidrug resistance in tumour cells by flow cytometry. Br J Cancer 72: 543-549, 1995.

24. Shukla S, Wu CP and Ambudkar SV: Development of inhibitors of ATP-binding cassette drug transporters: present status and challenges. Expert Opin Drug Metab Toxicol 4: 205-223, 2008.

25. Higgins CF: Multiple molecular mechanisms for multidrug resistance transporters. Nature 446: 749-757, 2007.

26. Baguley BC: Multidrug resistance in cancer. Methods Mol Biol 596: 1-14, 2010.

27. Mor G, Montagna MK and Alvero AB: Modulation of apoptosis to reverse chemoresistance. Methods Mol Biol 414: 1-12, 2008.

28. Fulda S and Debatin KM: Extrinsic versus intrinsic apoptosis pathways in anticancer chemotherapy. Oncogene 25: 4798-4811, 2006.

29. Wen J, Zheng B, Hu Y, et al: Establishment and biological analysis of the EC109/CDDP multidrug-resistant esophageal squamous cell carcinoma cell line. Oncol Rep 22: 65-71, 2009.

30. Longley DB and Johnston PG: Molecular mechanisms of drug resistance. J Pathol 205: 275-292, 2005.

31. Crowley E and Callaghan R: Multidrug efflux pumps: drug binding - gates or cavity? FEBS J 277: 530-539, 2010

32. Teodori E, Dei S, Martelli C, Scapecchi S and Gualtieri F: The functions and structure of ABC transporters: implications for the design of new inhibitors of Pgp and MRP1 to control multidrug resistance (MDR). Curr Drug Targets 7: 893-909, 2006.

33. Szakacs G, Paterson JK, Ludwig JA, Booth-Genthe C and Gottesman MM: Targeting multidrug resistance in cancer. Nat Rev Drug Discov 5: 219-234, 2006.

34. Calatozzolo C, Gelati M and Ciusani E, et al: Expression of drug resistance proteins Pgp, MRP1, MRP3, MRP5 and GST-pi in human glioma. J Neurooncol 74: 113-121, 2005.

35. Gruber BM, Bubko I, Krzyszton-Russjan J and Anuszewska EL: Synergistic action of doxorubicin and sulindac in human cervix carcinoma cells - studies on possible mechanisms. Med Sci Monit 16: R45-R51, 2010.

36. Ambudkar SV, Kimchi-Sarfaty C, Sauna ZE and Gottesman MM: P-glycoprotein: from genomics to mechanism. Oncogene 22: 7468-7485, 2003.

37. Nobili S, Landini I, Giglioni B and Mini E: Pharmacological strategies for overcoming multidrug resistance. Curr Drug Targets 7: 861-879, 2006.

38. Bellamy WT: P-glycoproteins and multidrug resistance. Annu Rev Pharmacol Toxicol 36: 161-183, 1996.

39. Juliano RL and Ling V: A surface glycoprotein modulating drug permeability in Chinese hamster ovary cell mutants. Biochim Biophys Acta 455: 152-162, 1976.

40. Ueda K, Cardarelli C, Gottesman MM and Pastan I: Expression of a full-length cDNA for the human 'MDR1' gene confers resistance to colchicine, doxorubicin, and vinblastine. Proc Natl Acad Sci USA 84: 3004-3008, 1987.

41. Gu W, Fang FF, Li B, Cheng BB and Ling CQ: Characterization and resistance mechanisms of a 5-fluorouracil-resistant hepatocellular carcinoma cell line. Asian Pac J Cancer Prev 13: 4807-4814, 2012.

42. Han MH, Yoo YH and Choi YH: Sanguinarine-induced apoptosis in human leukemia U937 cells via Bcl-2 downregulation and caspase-3 activation. Chemotherapy 54: 157-165, 2008.

43. Cory S and Adams JM: The Bcl2 family: regulators of the cellular life-or-death switch. Nat Rev Cancer 2: 647-656, 2002.

44. Salvesen GS and Dixit VM: Caspases: intracellular signaling by proteolysis. Cell 91: 443-446, 1997. 
45. Nunez G, Benedict MA, Hu Y and Inohara N: Caspases: the proteases of the apoptotic pathway. Oncogene 17: 3237-3245, 1998.

46. Cheng EH, Kirsch DG, Clem RJ, et al: Conversion of Bcl-2 to a Bax-like death effector by caspases. Science 278: 1966-1968, 1997.

47. Kluck RM, Bossy-Wetzel E, Green DR and Newmeyer DD: The release of cytochrome c from mitochondria: a primary site for Bcl-2 regulation of apoptosis. Science 275: 1132-1136, 1997.

48. Robinson LJ, Roberts WK, Ling TT, Lamming D, Sternberg SS and Roepe PD: Human MDR 1 protein overexpression delays the apoptotic cascade in Chinese hamster ovary fibroblasts. Biochemistry-Us 36: 11169-11178, 1997.

49. Bezombes C, Maestre N, Laurent G, Levade T, Bettaieb A and Jaffrezou JP: Restoration of TNF-alpha-induced ceramide generation and apoptosis in resistant human leukemia KG1a cells by the P-glycoprotein blocker PSC833. FASEB J 12: 101-109, 1998.
50. Tainton KM, Smyth MJ and Jackson JT, et al: Mutational analysis of P-glycoprotein: suppression of caspase activation in the absence of ATP-dependent drug efflux. Cell Death Differ 11: 1028-1037, 2004.

51. Mantovani I, Cappellini A, Tazzari PL, Papa V, Cocco L and Martelli AM: Caspase-dependent cleavage of 170-kDa P-glycoprotein during apoptosis of human T-lymphoblastoid CEM cells. J Cell Physiol 207: 836-844, 2006.

52. Gibalova L, Seres M and Rusnak A, et al: P-glycoprotein depresses cisplatin sensitivity in L1210 cells by inhibiting cisplatin-induced caspase-3 activation. Toxicol In Vitro 26: 435-444, 2012. 